\title{
Perfectibility of the mechanism of the ecological and industrial components' interaction in the development of the region
}

\author{
Polina Baboshkina \\ Astrakhan State Technical University \\ Institute of Economics \\ Astrakhan, Russia \\ kaa5497@yandex.ru
}

\author{
Elena Kozyrenko \\ Astrakhan State Technical University \\ Institute of Economics \\ Astrakhan, Russia \\ kaa5497@yandex.ru
}

\author{
Elmira Salakhova \\ Astrakhan State Technical University \\ Institute of Economics \\ Astrakhan, Russia \\ kaa5497@yandex.ru
}

\begin{abstract}
Negative human impact on the environment and irrational use of natural resources is an important problem at the present stage of economic development. Air pollution can affect the development of the region.

In the course of research an analytical work on an assessment of pollution index influence of environment on an ecological condition of the region was carried out, the management mechanism of development of the region's enterprises was developed, recommendations on reaching a compromise between sustainable ecological and economic development of an enterprise and benefit to society from its activity were given.

Based on the stipulated parameters, a two-dimensional scale of the criterion of sustainable ecological and economic development of the enterprise operating in the region was constructed, it allows to estimate in quantitative form the level of sustainable ecological and economic development of the enterprise of the given region upon preestimated indications of the condition of its productive-economic and ecological systems that can become the tool for the analysis of productive activity and control of processes of environmental protection from industrial pollution.
\end{abstract}

Keywords—component, formatting, style, styling, insert

\section{INTRODUCTION}

The progressive advance of agriculture, mining and processing production, population growth led to a conflict of the natural environment with economic activity. The environmental crisis is becoming a real threat to all mankind.

Analysis of scientific publications revealed that research in this area is conducted quite intensively, but the researchers` attention is focused mainly on its financial and economic issues, while the environmental component of the region's development is neglected. This problem is also relevant for the Astrakhan region.

The aim of this study is to develop the theoretical and methodological foundations of the interaction mechanism between the environmental and industrial components in the region`s development.

\section{MATERIALS AND METHODS (MODEL)}

The article uses methods based on the principles of dialectic-materialistic approach to the problem under study. The main is the dialectical method, the use of which involves the study of human production activities impact for the extraction and processing of natural gas, sulfur and petroleum products, the discharge of contaminated wastewater on the ecological situation of the region in the inextricable connection and in the development. When describing the situation on the human production activity impact on the environmental component, the methods of analysis and synthesis, comparison, graphic method are used. In the working-out of recommendations for reaching a compromise between sustainable ecological and economic development of the enterprise and benefit to society from its activity, the methods of logical and expert analysis and expert assessments are used.

The empirical base of the research is the materials of the official websites of the Federal State Statistics Service, the office of the Federal State Statistics Service of the Astrakhan region and the Republic of Kalmykia, the Ministry of 
economic development of the Russian Federation, and other organizations.

\section{RESULTS AND DISCUSSION}

The world community is seriously concerned about globalization of negative human impact on the environment and irrational use of natural resources. To preserve nature, we need to reconsider our attitude to the use of resources and life on the planet.

The report of the European Environment Agency (2010) proposes a transition to a "green" economics that provides opportunities for self-restoration of ecosystems and preservation of their structure by reducing consumption and productive use of all types of natural resources. It is also planned to increase public investments in the natural environment, in scientific research on the development and creation of environmentally friendly products and technologies, improvement of the taxation system and the mechanism of paid environmental management. In many developed countries there is the development and implementation of elements of the Base schema of the Environmental and Economic Accounting System (EAC) for integrating environmental friendliness in the National Account System. [1, p.68]

Last 2017 year was declared the year of ecology in Russia, it revealed the state's attention to environmental issues once again, it emphasized their extreme relevance at the present stage of social development and the need for a complex approach to solution of environmental problems.

In 2012 "Basic Principles of State Policy in the field of environmental development of the Russian Federation for the period up to 2030" were developed, and in 2014 the state program of the Russian Federation "Environmental Protection" for 2012-2020 was approved, which was adjusted and supplemented in subsequent years. Thus, environmental problems are constantly in the limelight of the state and nevertheless in this direction there are still a lot of unsolved problems.

Due to its geopolitical position, some factors, such as low population density and vast territory, allow us to state the fact that in general, the environmental situation in Russia is not as gloomy as in other countries. However, inequality of living conditions, the formation of urban agglomerations and a large number of existing enterprises for the extraction and processing of natural resources near densely populated areas do not contribute to spontaneous improvement of the environmental situation.

Astrakhan region is the largest hydrocarbon resource base in the European part of Russia and one of the leaders of Russian regions in the production of natural gas, sulfur and petroleum products. [2, p. 189] But, for example, due to the high content of acid components in Astrakhan gas "Gazprom dobycha Astrakhan" occupies the first place in the region in terms of emissions of harmful substances into the atmosphere, and the current quotas for emissions of sulfur dioxide and carbon dioxide into atmosphere are almost exhausted. The comparison of the growth rate of the number of emitted pollutants nationwide and in Astrakhan region is fairly interesting, table 1 .

The ratio of the growth rates of air emissions of pollutants in total and among other things by type of activity - mining and processing industries - nationwide and specifically in the Astrakhan region over the period of 2011-2016 are shown in figure 1 .

As can be seen in the diagram, shown in figure 1, the dynamics of the considered positions in Russia and in the Astrakhan region is virtually identical, although the trend of a small advance in the growth of emissions of pollutants in the considered type of activity in the Astrakhan region is noticeable. Moreover, the study of the average per capita emissions of pollutants into the atmosphere is even more dismaying. In this negative competition the Astrakhan region has a clear advantage, figure 2 .

The consequence of this situation is health deterioration of the Astrakhan region inhabitants. The leading place is occupied by respiratory diseases, both for children and adults. Air pollution can have an impact on the increased incidence of respiratory, central nervous system, blood, and oncopathology.

According to the Ministry of Health of the Astrakhan

TABLE 1 - Dynamics of indicators of environmental pollution by stationary sources, by type of economic activity in the Russian Federation for 2011-2016

\begin{tabular}{|c|c|c|c|c|c|c|}
\hline Indications & 2011 & 2012 & 2013 & 2014 & 2015 & 2016 \\
\hline $\begin{array}{l}\text { 1. Released pollutants into the atmosphere in the Russian } \\
\text { Federation in total, thousand tons }\end{array}$ & 19162 & 19630 & 18447 & 17452 & 17296 & 17300 \\
\hline $\begin{array}{l}\text { 2Among other things by type of activity - extraction of } \\
\text { minerals and manufactures across Russia, thousand tons }\end{array}$ & 12139,1 & 12534,9 & 12436,9 & 10876,2 & 10723,3 & 11060 \\
\hline $\begin{array}{l}\text { 3. Released pollutants into the atmosphere in the Astrakhan } \\
\text { region in total, thousand tons }\end{array}$ & 131,5 & 134,4 & 130,5 & 118,2 & 118,6 & 126,8 \\
\hline $\begin{array}{l}\text { 4. Among other things by type of activity - extraction of } \\
\text { minerals and manufactures across the Astrakhan region, } \\
\text { thousand tons }\end{array}$ & 109,5 & 111,1 & 103,7 & 98,7 & 99,6 & 106,5 \\
\hline 5. Population of Russia, million people. & 142,9 & 143,0 & 143,3 & 143,7 & 146,3 & 146,5 \\
\hline 6. The population of the Astrakhan region, million. people. & 1,010 & 1,014 & 1,014 & 1,017 & 1,021 & 1,017 \\
\hline $\begin{array}{l}\text { 7. The amount of pollutants released into the atmosphere by } \\
\text { type of activity-mining and processing industries per one } \\
\text { resident of Russia, kg }\end{array}$ & 84,9 & 87,7 & 86,9 & 75,7 & 73,3 & 75,5 \\
\hline $\begin{array}{l}\text { 8. The amount of pollutants released into the atmosphere by } \\
\text { type of activity-mining and processing industries per one } \\
\text { inhabitant of the Astrakhan region, } \mathrm{kg}\end{array}$ & 108,4 & 109,6 & 102,3 & 97,1 & 97,6 & 104,7 \\
\hline
\end{tabular}


region, the vast majority of deaths from air pollution occur due to cardiovascular diseases [3. p. 20]. It happens despite the fairly high investment in medicine and health care. According to Astrakhan doctors, it is quite obvious that the key role in the dynamics of morbidity of all age groups of the Astrakhan region population is played by adverse environmental factors associated with anthropogenic impact on the environment, such as emissions into the atmosphere, the impact of petrochemical enterprises and etc. Over the past 7 years, discharge of polluting wastewater into surface water bodies has decreased by $10.9 \%$, water losses during transportation have decreased by $11.7 \%$ (see Fig.3 and 4).

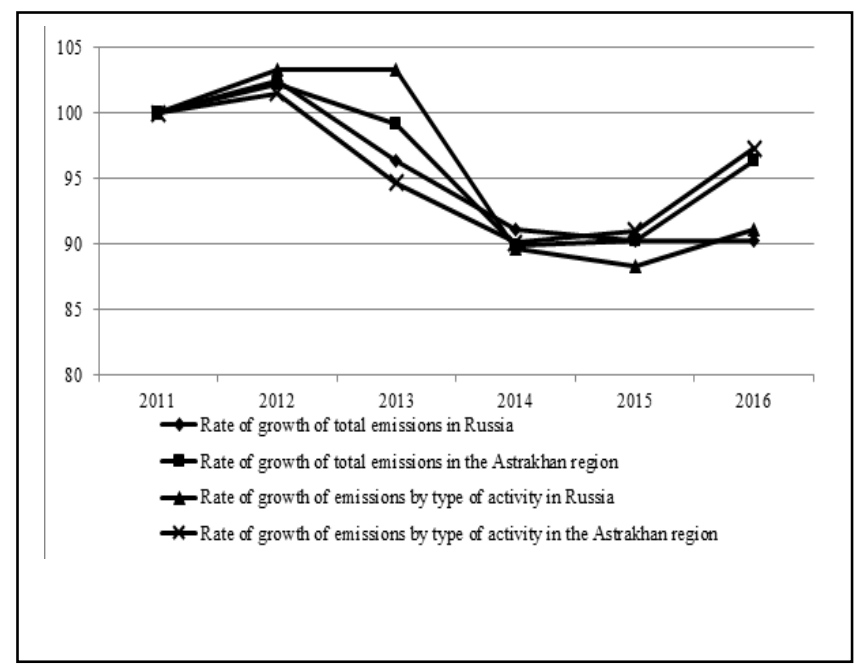

Fig. 1. The rate of growth of pollutants emissions into the atmosphere nationwide and in the Astrakhan region over the period of 2011-2016, \%

The analysis revealed that more than a half of the discharges of contaminated wastewater is carried out by electric power engineering entities, gas and water distribution $(55,7 \%), 92 \%$ of the total volume of the caught and neutralized polluting substances in the Russian Federation are carried out by enterprises of manufacturing industry and production organizations, distribution of electricity, gas and water, there are huge losses of water during transportation in agriculture and forestry, during gas, water and electricity production (58\% and $34 \%$ respectively).

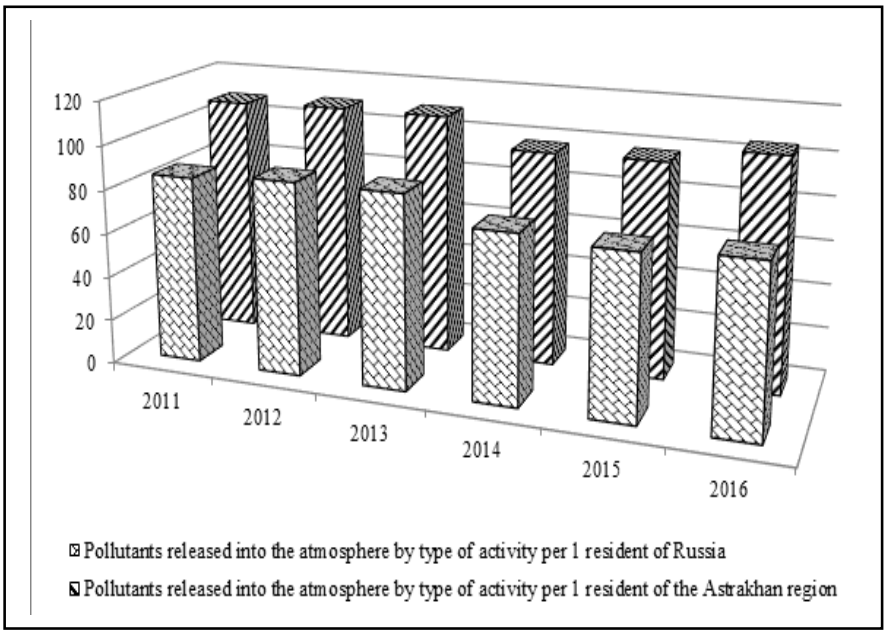

Fig. 2. The dynamics of the average per capita emissions of pollutants into the atmosphere nationwide and in the Astrakhan region over the period of 2011-2016, $\mathrm{kg} /$ person

Significant volumes of water intake from natural water bodies of Russia for use (in 2016- 61.3 billion $\mathrm{km}^{3}$ ), discharge of polluted waste water (in 2015 - 14.7 billion $\mathrm{km}^{3}$ ), among other objective factors, they have a negative impact on the living conditions of aquatic biological resources (especially fisheries), which are of great social and economic importance. In 2016 the discharge of contaminated wastewater amounted to 6.1 billion $\mathrm{m}^{3}$ in the Caspian sea basin, and 5.3 million $\mathrm{m}^{3}$ in the Volga river basin.

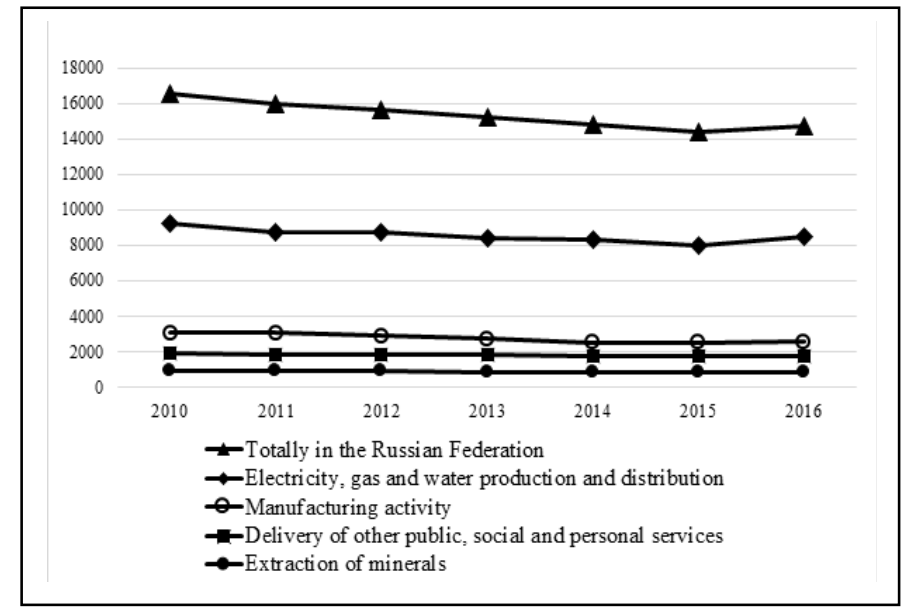

Fig. 3. Discharge of polluted wastewater into surface water bodies of the Russian Federation in 2010-2016, mln $\mathrm{m}^{3}$

The decrease in capture level in the Volga-Caspian fishery basin was due to critically low water flow in the Volga river during high water and continuing decline in the Caspian sea level (salinization of coastal waters), which had an adverse impact on reproduction conditions and habitat of passing and semi-passing fish. The lack of growth in the total number of seals in the Russian zone of the Caspian sea is a consequence of the negative impact on their habitat - intensive navigation and development of offshore oil and gas fields, the use of poaching gear and etc. [4, p.179] 
Enterprises cause great damage to the ecological system of the region to achieve high results of their activities. In order to reduce the environmental damage, caused by enterprises for the region, a need to develop a mechanism for managing the development of the enterprise appears.

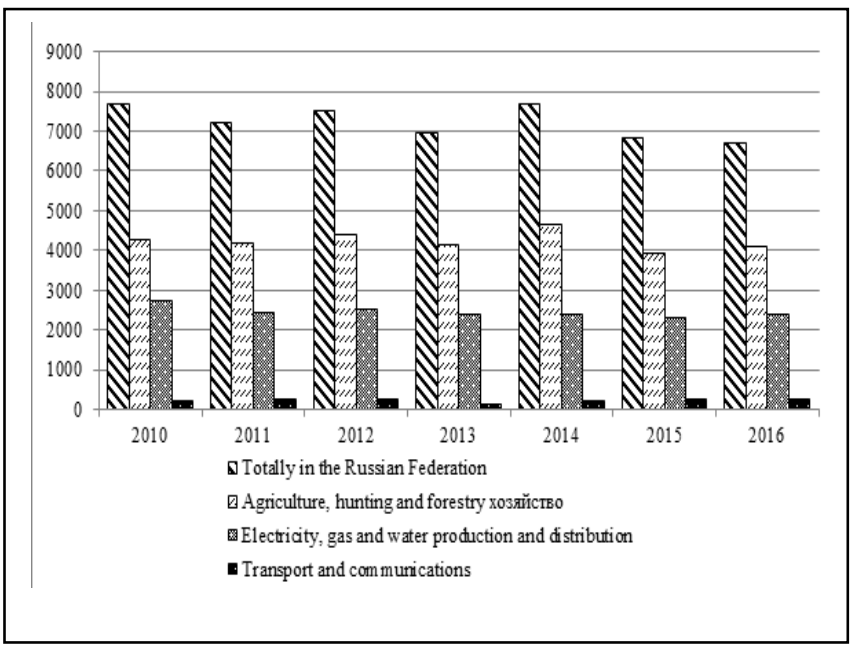

Fig. 4. Water losses during water transportation in Russia over the period of 2010-2016, $\mathrm{mln}^{3}$

Such management should represent a compromise between the sustainable ecological and economic development of the enterprise and the benefits to society from its activities.

To assess the degree of sustainable ecological and economic development of the enterprise operating in the region, it is possible to determine the criterion based on the following indicators:

1. Condition of productive-economic system of the enterprise - «A»;

2. Condition of the ecological system of the region $-\langle\mathrm{B} »$;

3. Social constituent of the region $-\ll \mathrm{C} »$.

It should be noted that the condition of productiveeconomic system is determined mainly by indicators characterizing the functioning of the enterprise itself. By contrast, indicators describing the condition of the ecological and social systems are external to the enterprise and characterize the impact of the enterprise's activity on the external environment.

The sustainable ecological and economic development of an enterprise is influenced by the indicators that formed the basis for the classification of factors. To enable comparison, factors must be quantified, have the same unit of measure, and have the same variation range. [5, p. 86]

If we take the maximum possible benefit from the activities of an enterprise equal to one, the variation range of the possible benefits will be as follows: $0<\mathrm{C} \leq 1$.

As indicators $\mathrm{A}, \mathrm{B}$ and $\mathrm{C}$ have the same variation range, so:

$$
\mathrm{C}=\mathrm{Cmax}-(\mathrm{A}+\mathrm{B}), \text { or } \mathrm{C}=1-(\mathrm{A}+\mathrm{B})
$$

The sum of A and B is a parameter that affects the size of benefits to society from the activities of an enterprise.

The maximum value of the sum of indicators $\mathrm{A}$ and $\mathrm{B}$ is the state of the productive-economic system of an enterprise $\mathrm{A}$ and the state of the ecological system of the region $\mathrm{B}$, where $\mathrm{C}=\mathrm{B}$. If the indicators of the state of the region's ecological system and the social component of the region are equal, the benefit received by society $\mathrm{C}$ will be fully spent on covering environmental damage $B$ (figure 5). If $\mathrm{C}<[1-(\mathrm{A}+\mathrm{B})]$ a damage appears, which cannot be met by the obtaining benefit.

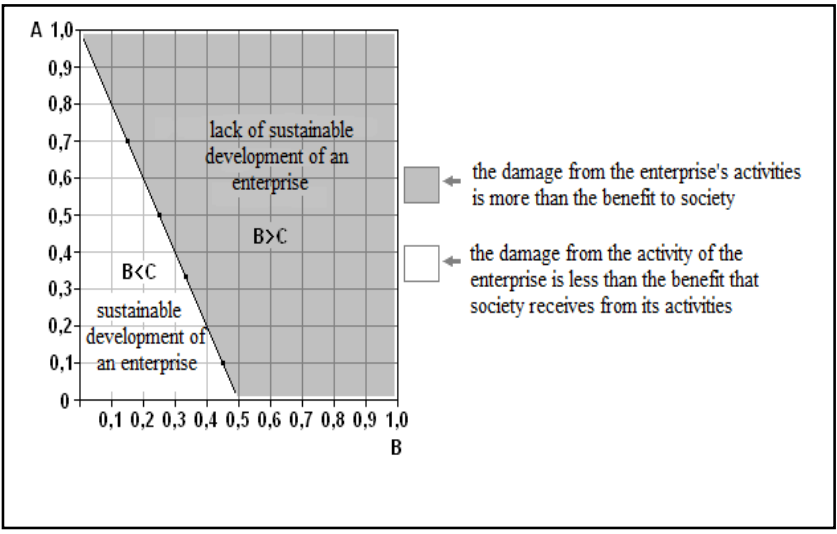

Fig. 5. Scale of criterion of sustainable ecological and economic development of the region`s enterprise

Therefore, sustainable ecological and economic development should be considered as the state of the productive-economic system of an enterprise $A$, which in total with the state of the region's ecological system B, allows the society to get more benefits than expenses for reducing damage, i.e. :

$$
\mathrm{C}>[1-(\mathrm{A}+\mathrm{B})] \text {, where } \mathrm{C}>\mathrm{B}
$$

The boundary between sustainable and non-sustainable ecological and economic development of the region will be equality 3 .

$\mathrm{C}=[1-(\mathrm{A}+\mathrm{B})]$, where $\mathrm{C}=\mathrm{B}$ or $\mathrm{A}+2 \mathrm{~B}=1$

Possible options for sustainable ecological and economic development of an enterprise are shown in figure 6.

On the basis of these examples, a two-dimensional scale of the criterion of sustainable ecological and economic development of an enterprise, operating in the region, is constructed. This scale makes it possible to quantify the level of sustainable ecological and economic development of an enterprise in the region on the basis of pre-calculated indicators of the state of its productive-economic system A and the state of the ecological system in the region $\mathrm{B}$, which can become a tool for the analysis of operating activities and management of environmental protection from industrial pollution.

According to the results of an enterprise proposed evaluation, it is necessary to draw a conclusion about its ecological and economic state and environmental policy. In case of non-sustainable ecological and economic development of an enterprise it is necessary to introduce toughening of 
ecological requirements and strengthening of responsibility for violation of environmental protection legislation of the Russian Federation. Such actions in the midterm will lead to an increase of environmental costs in the real economy sector, which should be compensated by accelerating the technical production modernization, innovations stimulating, improving the competitiveness of enterprises in the region and Russian economy as a whole. [6, p. 136]

In case of sustainable ecological and economic development of an enterprise at the regional level, various support tools should be applied. It is necessary to introduce result-oriented regulatory approaches - a high level of ecological and economic development, providing incentives for enterprises to improve environmental and economic performance.

Regional authorities may invite enterprises to participate in the assessment of the ecological and economic condition of an enterprise.

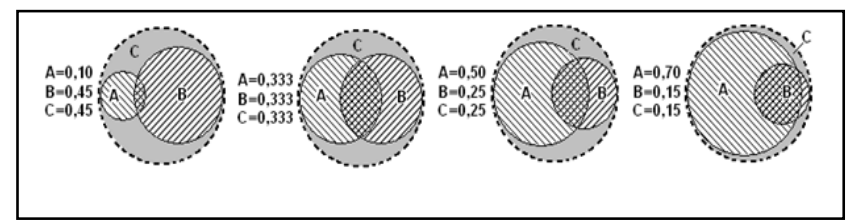

Fig. 6. Options for sustainable ecological and economic development of an enterprise in the region where $\mathrm{B}=\mathrm{C}$

According to the assessment results, in case of a high level of ecological and economic development, the company can be issued an environmental certificate, the presence of which can attract additional consumers of the company's products.

This method of encouragement can contribute to the output of products, with minimal damage to society.

\section{CONCLUSION}

As a result of the study, it was noted that the environmental situation in Russia is somewhat better than in a number of world countries, however, despite the state attention to this problem, it remains extremely acute. The situation in the Astrakhan region is even more complicated. Thus, the rate of growth of pollutants emissions into the atmosphere nationwide in Russia and in the Astrakhan region for the period of 2011-2016 is virtually unchanged. At the same time, the average per capita emissions of pollutants into the atmosphere, including by type of activity - mining and manufacturing - in the Astrakhan region exceeds the same figures for Russia in 2011 - by $27 \%$, and in 2016 - by $40 \%$. The health of residents of the Astrakhan region is deteriorating. Both children and adults respiratory diseases take a leading place. Oil and gas fields development on the Caspian shelf has led to a decrease in the total number of seals, the volume of fish catch, adversely affected the conditions of reproduction and habitat of fish.

With the aim of possible reducing environmental damage, caused by region`s companies, a mechanism of enterprise`s development management was proposed, providing a compromise between sustainable ecological and economic development of an enterprise and social benefit from its activities. The scale of criterion of an enterprise's ecological and economic development was constructed. It made in a quantitative form an assessment of development level in preestimated parameters of a condition of productiveeconomic system of an enterprise and a condition of ecological system of the region was constructed. This assessment of the company's environmental policy and its impact on the ecology and social environment of the region allows using various support tools at the regional level, which will contribute to the further growth of productive-economic potential of the enterprise.

\section{References}

[1] Salakhova E.K. Natural-resource and economic accounting of fish stocks: problems of implementation [Prirodno-resoursnyi i ekonomicheskyi uchyot rybnyh zapasov: problemy vnedreniya]./Salakhova E. K. //Bulletin of Astrakhan State Technical University [Vestnik Astrahanskogo gosudarstvennogo tekhnicheskogo universiteta]. Series: Economics. 2017. № 1 (march). 124p. - P.67-77.

[2] Baboshkina P. A., Stein V. V. Economic policy of the Astrakhan region and geopolitical stability in the Caspian region [Ekonomicheskaya politika astrahanskoy oblasti i geopoliticheskaya stabilnost Prikaspiiskogo regiona]. Collection of materials of the 4th international scientific and practical conference "Fundamental science and technology - future developments" [Sbornik materialov 4 mezhdunarodnoy nauchnoprakticheskoy konferencii "Fundamentalnaya nauka i tekhnologii perspektivnye razrabotki"] - 29-30 September 2014. Volume 3 North Charleston, SC, USA 29406 2014-245p.

[3] Baboshkina P. A., Tarutanova T. A., Golovin, A. M. "Oil and gas industry in the Astrakhan region" ["Neftegazovaya otrasl v Astrahanskoy oblasti"]. Collection of materials of International scientific and practical conference "Innovations, technologies, science: collection of articles of the international scientific-practical conference" [Sbornik materialov MNPK "Innovacii, tekhnologii, nauka: sbornik statey mezhdunarodnoy nauchnoprakticheskoy konferencii"] (January 25, 2017. Perm) in 4 volumes. Volume 1 - Ufa: AETERNA,2017. - 324p.

[4] Salakhova E. K. Sustainable development of the Astrakhan region [Ustoichivoye razvitie Astrahanskogo regiona] / Salakhova E. K. //Modern aspects of economy [Sovremennye aspekty ekonomiki].-2002.- No. 1 (14).-P. 178-184.

[5] Kozyrenko E. I. Method of determination of sustainable ecological and economic development of industrial enterprises of construction materials. Prospects of development of the construction complex [Metodika opredeleniya ustoichivogo ekologo-ekonomicheskogo razvitiya predpriyatyi promyshlennosti stroitelnyh materialov. Perspektivy razvitiya stroitelnogo kompleksa] / / Articles of the VI International scientific and practical conference (as part of the celebrations dedicated to the 20th anniversary of the Astrakhan Institute of Civil Engineering) [Materialy VI Mezhdunarodnoy nauchno-prakticheskoy konferencii ( $\mathrm{v}$ ramkah prazdnichnyh meropriyatyi, posvyaschennyh 20-letiyu Astrahanskogo inzhenernj-stroitelnogo instituta)] 22-26 October 2012-Astrakhan: "AICE", 2012-vol.1.-294 p.-p. 82-88.

[6] Kozyrenko E. I. Management of sustainable development of industrial enterprises of construction materials [Upravleniye ustoichivym razvitiem predpriyatii promyshlennosti stroitelnyh materialov]. Bulletin of Astrakhan State Technical University. Ser.: Economy [Vestnik Astrahanskogo gosudarstvennogo tekhnicheskogo universiteta. Seriya: Ekonomika] -2010.№2- p. 130-137. 